\title{
Density and Developmental Stage of Range Caterpillar Hemileuca oliviae Cockerell, as Affected by Topographic Position
}

\author{
W.D. BEAVIS, J.C. OWENS, M. ORTIZ, T.S. BELLOWS JR., J.A. LUDWIG, E.W. HUDDLESTON
}

\begin{abstract}
Population density and larval development of range caterpillar (Hemileuca oliviae Cockerell) were influenced by topographic position. Larval populations on ridges and upper slopes were in earlier developmental stages and had lower densities than populations on swales and lower slopes. Plant species composition, vegetative productivity, ground cover, and soil surface temperatures were suggested as habitat factors that might explain these differences.
\end{abstract}

The range caterpillar, Hemileuca oliviae Cockerell, is a major insect pest on approximately 7.7 million ha of shortgrass prairie in New Mexico and adjacent areas of Colorado, Oklahoma, and Texas (Ainsley 1910, Watts and Evcrett 1976). Blue grama (Bouteloua gracilis (H.B.K.) Lag. ex Steud.), the dominant forage species of these prairies, appears to be the preferred food source of $H$. oliviae, although it also feeds on other grasses (Capinera 1978, Wildermuth and Caffrey 1916). Since 1885 there have been at least four major range caterpillar outbreaks. The most recent outbreak was first noticed around 1960 and has been characterized by population fluctuations due to natural mortality factors and insecticide suppression programs (Watts and Everett 1976).

The impact of the range caterpillar on rangeland is expressed in three major ways (Huddleston et al. 1976). (1) The larvae, which grow from $5.0 \mathrm{~mm}$ to almost $100 \mathrm{~mm}$ in 8 to 12 weeks, consume large amounts of foliage. While feeding, larvae waste additional forage when they cut off parts of leaves without eating them. (2) Grass not eaten by the caterpillars is rendered unpalatable to livestock by the irritating spines on the larvae and on their cast skins, which remain attached to the grass throughout the remainder of the growing season and into the winter. (3) The damaged rangeland is subject to soil erosion by wind and water, which has long-term implications.

Watts and Everett (1976) suggested that environmental factors such as soil type, plant productivity, effective precipitation, and ground cover affect population density of range caterpillar. Field researchers conjectured that plant species composition, plant productivity and ground cover are related to topographic position in the rolling terrain of east central New Mexico. Field researchers also observed that there were more range caterpillar larvae in swale and lower slope areas than on adjacent ridges and upper slopes. Additionally, larvae in swale and lower slopes were observed to be in later developmental stages than larvae on upper slopes and ridges. This study was designed to confirm these observations

Beavis, Owens, Bellows, and Huddleston are with the Department of Entomology and Plant Pathology, New Mexico State University, Las Cruces, New Mexico 88003 Ortiz is with the Department of Experimental Statistics and Ludwig with the Department of Biology of the same university.

This article was submitted as Journal Article 774, New Mexico Agricultural Expe riment Station, Las Cruces, New Mexico. It reports on work supported in part by USDA/SEA/CR Research Grant 801-15-35.

Manuscript received June 4, 1980. relating vegetation and range caterpillar populations to topography.

\section{Methods}

Three study sites were selected randomly during July 1978 in a region of northeastern Lincoln Co., New Mexico, known to be infested by range caterpillar. The physiognomy of northeastern Lincoln Co. consists of a grassland on gently rolling hills at an altitude of about $1,650 \mathrm{~m}$. Slopes were less than $10 \%$ and relief was less than $100 \mathrm{~m}$ from swale to ridge. Sites in areas that had been sprayed in previous years to control range caterpillar were avoided. Four topographic positions (ridges, upper slope, lower slope, and swale) were delineated at each site. Two sites (site 1 and 2) included both north and south facing slopes and one site (site 3) included both east and west facing slopes. The vegetation, soil, and range caterpillar population characteristics were quantified for each topographic position.

Grass species were sampled along four arbitrarily-paced $100-\mathrm{m}$ transects per landscape position. The line intercept technique described by Canfield (1941) was used to determine vegetative composition along these transects. Forbs and half-shrubs were recorded in separate categories. Forbs were grouped as a single category because composition of annual forbs was highly variable from site to site due to intermittent and scattered rainfall during the study period. All half-shrubs except broom snakeweed (Xanthocephalum sarothrae (Pursh.) Skinners) were recorded as a single category because a preliminary survey of each site suggested that half-shrubs other than snakeweed contributed less than $1 \%$ to the total species composition. Total ground cover was estimated using a point frame with 10 pins inclined at $32.5^{\circ}$ from vertical and spaced $5 \mathrm{~cm}$ apart (Levy and Madden 1933). The point frames were placed at $2.5-\mathrm{m}$ intervals along the four $100-\mathrm{m}$ transects at each of the four topographic positions. The points of contact between pin and ground were recorded in four categories: litter, soil, rock fragments (those particles on the soil surface with diameters greater than $2 \mathrm{~mm}$ ), and basal crown of plants. Soil depth was sampled for each topographic position. Depth to a petrocalcic horizon, a calcic horizon, or to bedrock was mcasured (Soil Survey Staff 1975) at four locations in each topographic position.

Niche or $\alpha$-diversity, a measure of within habitat species diversity, was determined for each topographic position by the BergerParker dominance index (Berger and Parker 1970). This index $D$ is the proportion of the total sample size due to the most abundant species.

$$
D=N_{\mathrm{d}} / N_{\mathrm{t}}
$$

where $N_{\mathrm{d}}$ refers to the abundance of the dominant species, and $N_{\mathrm{t}}$ is the total sample size. This index can be found in Table 1 by 
Table 1. Prevalent plant species (greater than 5\%) of four topographic positions at three range caterpillar infested sites in northest Lincoln Co., N. Mex. (July 1978).

\begin{tabular}{|c|c|c|c|c|}
\hline \multirow[b]{2}{*}{ Topographic position } & \multirow[b]{2}{*}{ Plant species } & \multicolumn{3}{|c|}{ Percentage composition 1} \\
\hline & & Site 1 & Site 2 & Site 3 \\
\hline \multirow[t]{4}{*}{ Ridge } & Blue grama & 8.3 & 14.0 & 17.2 \\
\hline & Assorted Forbs & 31.3 & 26.8 & 20.8 \\
\hline & Snakeweed & 18.3 & 17.7 & 14.4 \\
\hline & $\begin{array}{l}\text { New Mexico } \\
\text { feathergrass }\end{array}$ & 13.0 & 4.2 & 10.0 \\
\hline \multirow[t]{7}{*}{ Upper Slope } & Blue grama & 24.0 & 8.0 & 18.8 \\
\hline & Assorted Forbs & 13.7 & 23.7 & 22.8 \\
\hline & Wright's three-awn & 3.6 & 20.7 & 9.8 \\
\hline & Snakeweed & 17.2 & 11.7 & 9.1 \\
\hline & Wolftail & 4.4 & 15.1 & 5.8 \\
\hline & Sideoats grama & 12.8 & 8.2 & 7.4 \\
\hline & $\begin{array}{l}\text { New Mexico } \\
\text { feathergrass }\end{array}$ & 11.8 & 1.7 & 7.5 \\
\hline \multirow[t]{3}{*}{ Lower Slope } & Blue grama & 40.6 & 61.6 & 56.7 \\
\hline & Sand dropseed & 12.3 & 7.4 & 4.0 \\
\hline & Ring muhly & 0.6 & 11.7 & 15.4 \\
\hline \multirow[t]{4}{*}{ Swale } & Blue grama & 43.1 & 33.1 & 4.3 \\
\hline & Buffalo grass & 0.0 & 0.0 & 61.3 \\
\hline & Creeping muhly & 22.7 & 5.0 & 3.2 \\
\hline & Galleta grass & 4.9 & 18.8 & 0.0 \\
\hline
\end{tabular}

'The Berger-Parker Dominance Index, a measure of $\alpha$-diversity, can be obtained by dividing the most abundant species by 100 .

converting the percent composition of the most abundant species to a proportion.

Coefficient of community $(C C)$ is an index of $\beta$-diversity, or species diversity among habitats, and was calculated for grass species from the following equation (Whittaker 1975):

$2 \times$ Number of grass species common to both vegetative $C C=$ samples

sum of grass species from both vegetative samples

There were 12 vegetative samples in this study (four topographic positions at each of the three sites). The coefficient of community was calculated for all possible pairs of vegetative samples. The $C C$ index could range from 0.0 to 1.0 , with a value of 0.0 indicating no species in common to the two vegetative samples and a value of 1.0 indicating exactly the same grass species occur in both vegetative samples.

The polar ordination technique of Bray and Curtis (1957) was used to depict graphically the relationship of the vegetation to an environmental gradient. This technique represents each vegetative sample as a point on line. The relative distance between the points representing the vegetative samples was based on the Pythagorean Theorem applied to the vegetative similarities of the sites (topographic positions) as determined by the $C C$. Because small values of $C C$ imply that any two vegetative samples being compared are dissimilar, the smallest $C C$ value would result from a comparison between least similar vegetative samples. Subtracting this minimum $C C$ value from unity results in a quantitative measure of similarity between the two least similar sites. Call this distance $L$. Therefore, each vegetative sample may bc related to these least similar vegetative samples as follows:

$$
X_{\mathrm{k}}=\frac{L^{2}+\mathrm{D}^{2}{ }_{1 \mathrm{k}}-\mathrm{D}^{2}{ }_{2 \mathrm{k}}}{2 L}
$$

where each $X_{\mathrm{k}}$ has a value between 0.0 and $L$ and the values $D_{1 \mathrm{k}}$ and $D_{2 \mathrm{k}}$ are the distances from the two least similar vegetative samples. This technique has been thoroughly discussed by Bray and Curtis (1957) and Whittaker (1975).

The population density of range caterpillar larvae was estimated for each topographic position during the week of July 15. The number of larvae in ten 50-m by $1-\mathrm{m}$ belt transects in each topographic position were recorded according to their developmental stage. Differences in mean larval densities were tested with analysis of variance. The experimental design was randomized complete block, where sites were blocks and landscape positions were treatments. Larval densities werc transformed using logarithms to stabilize the variances which for these data was a power function of the mean (Southwood 1978). Independence of developmental stage to landscape position was tested using a two-way contingency table for each site.

\section{Results and Discussion}

Dominance indices for the topographic positions indicated that dominance differed between lower and upper topographic positions. A few species clearly dominated the vegetation in the swales and on the lower slopes (Table 1). Dominant plants in the swales were blue grama at sites 1 and 2, or buffalograss (Buchloe dactyloides (Nutt.) Engelm.) at site 3. Secondary species of the swales were either creeping muhly (Muhlenbergia repens (Presl.) Hitch.) at site 1 or galleta grass (Hilaria jamesii (Torr.) Benth.) at site 2. Blue grama dominated lower slopes at all three sites. Secondary species of the lower slopes, however, were different from those found in the swales. The secondary species were either sand dropseed (Sporobolus cryptandrus (Torr.) A. Gray) found at site 1, or ring muhly (Muhlenbergia torreyi Kunth.) Hitchc.) found at sites 2 and 3 . In contrast to the two lower topographic positions, the upper slopes and ridges did not exhibit high dominance indices. The two upper topographic positions were characterized by assorted forbs, blue grama, broom snakeweed, New Mexico feathergrass (Stipa neomexicana (Thurb.) Scribn.), Wrights threeawn (Aristida wrightii Nash.), wolftail (Lycurus phleoides H.B.K.), and sideoats grama (Bouteloua curtipendula (Michx.) Torr.).

The coefficients of community for all possiblc pairs of topographic positions were organized into a matrix as described by Southwood (1978). This matrix indicated that vegetation found in the swales was different from the vegetation of any other topographic position. Additionally, swales were less uniform from site to site than either the upper slopes and ridges or the lower slopes. The vegetation of the lower slopes at the different sites was similar but was different in vegetative composition from the two upper topographic positions. The upper slopes and ridges were vegetatively similar from site to site. The species composition of the ridge at site 2 , however, was intermediate between the lower slopes and the two upper topographic positions due to the presence of plant species common on both upper and lower slopes. The presence of the lower slope plants on this ridge was due to deeper soils than the ridges at the other sites (Table 2). The polar ordination graphically

Table 2. Ground cover and soil depth associated with topographic position at three range caterpillar infested sites in northeast Lincoln Co., N. Mex. (August 1978).

\begin{tabular}{llccc}
\hline \hline Site & & $\begin{array}{c}\text { Ground } \\
\text { cover } \\
(\%)\end{array}$ & $\begin{array}{c}\text { Rock } \\
\text { frag- } \\
\text { ments } \\
(\%)\end{array}$ & $\begin{array}{c}\text { Avg. } \\
\text { soil } \\
\text { depth } \\
(\mathrm{cm})\end{array}$ \\
\hline 1 & Topographic position & 27.25 & 30.00 & 23.3 \\
& Ridge & 25.50 & 29.25 & 20.3 \\
& Upper Slope & 48.75 & 3.25 & 37.6 \\
& Lower Slope & 54.25 & 0.30 & 100 \\
& Swale & 35.25 & 15.00 & 32.1 \\
& Ridge & 29.75 & 12.00 & 22.2 \\
& Upper Slope & 44.50 & 6.50 & 37.6 \\
& Lower Slope & 73.75 & 0.00 & 100 \\
& Swale & 30.00 & 13.00 & 21.2 \\
& Ridge & 23.50 & 38.25 & 18.6 \\
& Upper Slope & 49.25 & 1.25 & 38.1 \\
& Lower Slope & 62.50 & 0.50 & 100 \\
\hline
\end{tabular}




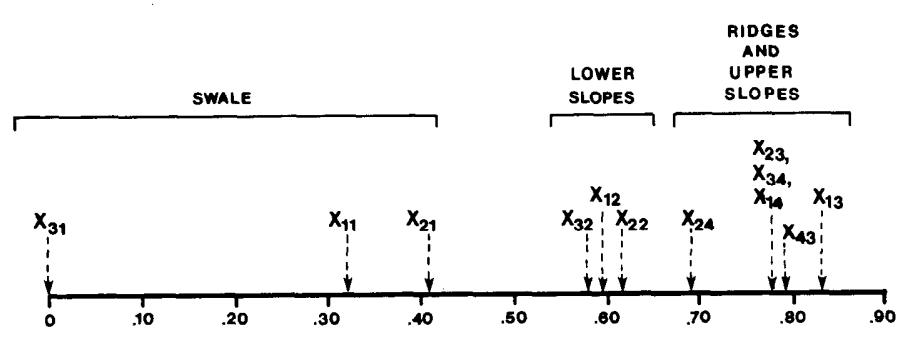

Fig. 1. Polar ordination based on plant species composition of four topographic positions at three range caterpillar infested sites in Lincoln Co., N. Mex. (July 1978). Ordinated landscape positions are shown by $X_{\mathrm{ij}}$, where $i$ represents site and $j$ represents landscape position $(j=l$, swale; $j=2$, lower slope; $j=3$, upper slope; $j=$ ridge).

depicted these differences between the vegetation at each topographic position (Fig. 1). The first three topographic positions in Figure 1 are the swales from all three sites. The swale topographic position at site 3 is distinctly separated from the swales at the other two sites. This large distance was expected because the dominant species of the swale at site 3 was buffalograss, whereas blue grama was dominant in the swales at the other two sites. Lower slopes

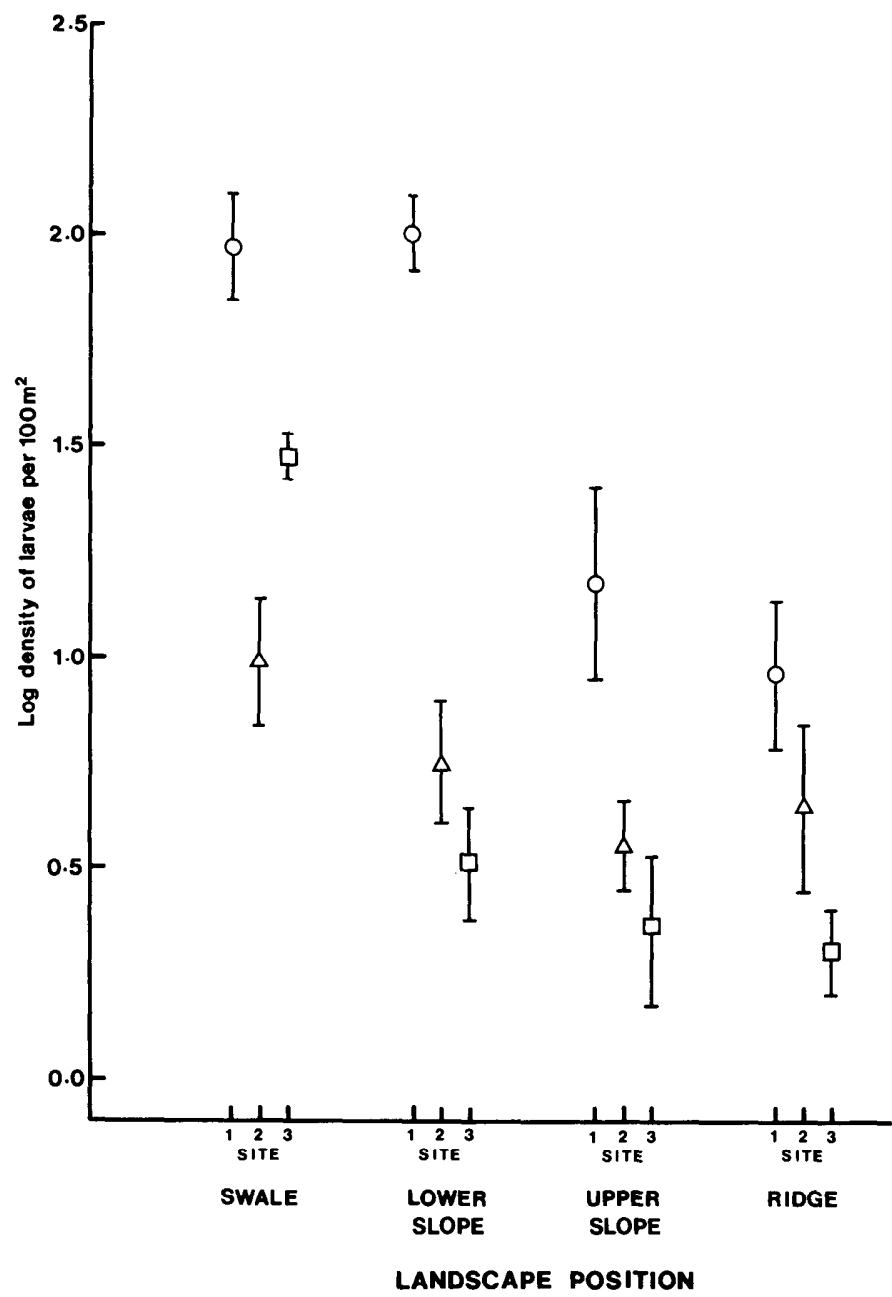

Fig. 2. The influence of topographic position on larval densities of range caterpillar at three sites in Lincoln Co., N. Mex. July 22-August 4, 1978). Means for site 1 are indicated by circles, means for site 2 are indicated by triangles, and means for site 3 are indicated by squares. Cross hatches indicate \pm one standard error of the mean. formed a tight cluster around 0.60 on the ordination axis, reflecting their vegetative similarity. The two upper topographic positions were grouped around 0.80 with the exception of the ridge at site 2 . The vegetation at this topographic position, included species common to both lower slopes and the two upper topographic positionstand consequently was placed at 0.70 , midway between the lower slopes and the two upper topographic positions.

Ground cover characteristics and soil depth, like vegetation, changed with topographic position (Table 2). Ground cover was lowest on the two upper topographic positions, the lower slopes had an intermediate amount of ground cover and the swales had the highest percentage ground cover. The percentage of the soil surface occupied by rock fragments was grcatest on the two upper topographic positions. Rock fragments were scarce on the lower slopes and rare on the swales. Soil depth increased from about 23 $\mathrm{cm}$ for the two upper topographic positions to about $38 \mathrm{~cm}$ for the lower slopes and to over $100 \mathrm{~cm}$ in the swales. These characteristics, when associated with their respective topographic positions, indicate that the line along which the topographic positions were located (Fig. 1) represents a complex gradient. The trends in ground cover and soil depth indicate that water-holding capacity decreased from the swales toward the ridges. Additionally, more water would run off the ridges and upper slopes due to the high percentage of rocks on the soil surface. Because swales and lower slopes receive greater effective precipitation and have deeper soil profiles, plant productivity should be greater on these landscape positions; future ecological studies should focus on the influence of plant productivity on range caterpillar survival.

Larval densities were significantly different among topographic postions $(0.10>P>0.05)$. At all three sites larval densities in the swales wcre greater than densities on the two upper topographic positions and there was a general trend of decreasing density along the gradient from swales to ridges (Fig. 2). Also, larval developmental stage was significantly dependent on topographic position at all three sites $(P<0.005)$. This phenomenon is shown by the histogram in Figure 3 where percentage of the total number of larvae in each instar was plotted for each topographic position. At all four landscape positions most of the population was in the third larval stage. However, fourth and fifth instar larvae made up a larger percentage of the population in the swales than did the larvae in the first and second larval stages. On the lower slopes over $60 \%$ of the larvae were in the third larval stage, and the rest of the population consisted of more first and second stages than fourth and fifth stages. In contrast to the populations on the lower topographic positions, $90 \%$ of the larval population was in the first

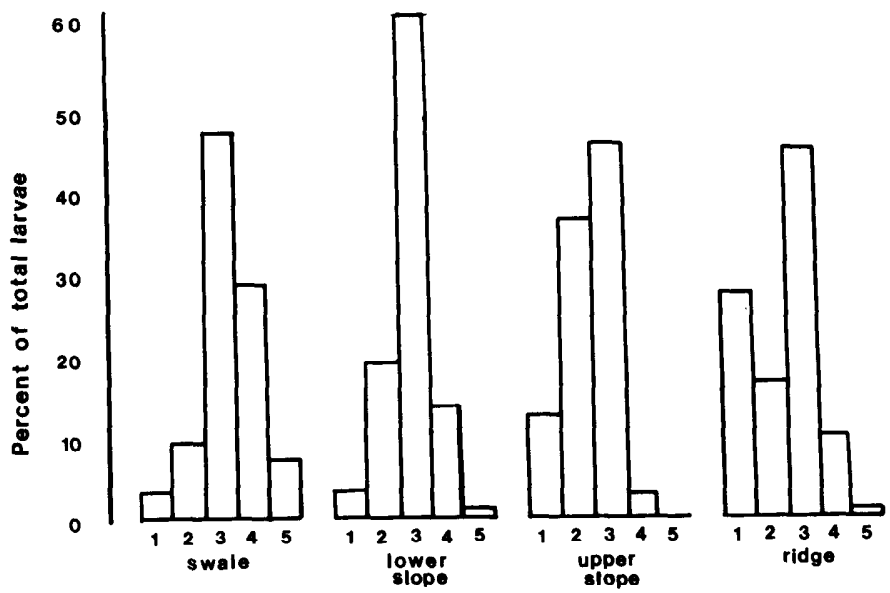

Larval stage

Fig. 3. Percentage of range caterpillar larvae by development stage and topographic position for three sites at Lincoln Co., New Mexico (July 22-August 4, 1978). 
three stages on the upper slopes and ridges. Thus, the two upper topographic positions were characterized by populations consisting of earlier larval stages.

In this study we have noted that topography was related to vegetative composition, ground cover, soil depth, and range caterpillar densities and developmental stages. If detailed vegetation or soil maps of the study area were available, it is likely that plant communities, or habitats, would provide a better ecological base for the study of influences on range caterpillar. However, the results of this study provide insight into the habitat factors that will influence populations of range caterpillar. Differences in vegetative composition will influence the diet of range caterpillar, and our unpublished rearing studies indicate that different host plant species greatly influence both development and mortality of range caterpillar. Not only is the quality of the diet important, but the quantity of forage also would influence survival of range caterpillar. It has already been suggested that productivity in the lower topographic positions was higher. Ground cover influences the microenvironment at the soil surface, especially temperature (Tomanek 1969). We observed during this study that range caterpillar larvae survive when placed on a soil surface with high ground cover, but die when placed on hot soils with little ground cover.

These results have strong implications for rangeland pest management. Insect pest management programs rely on accurate surveys of larval densities to monitor pest populations and maximize cost effectiveness. Sampling would be more efficient and reliable if topographic positions were incorporated into surveys of larval densities and developmental stage.

\section{Literature Cited}

Ainsley, C.N. 1910. The New Mexico range caterpillar. U.S. Dep. Agr. Bureau of Entomology. Bull. No. 85:57-96.

Berger, W.H., and F.L. Parker. 1970. Diversity of planktonic foraminifera in deep sea sediments. Science 168:1345-1347.

Bray, S.R., and C.T. Curtis. 1957. An ordination of the upland forest communities of southern Wisconsin. Ecol. Monogr. 27:325-349.

Canfield, R.H. 1941. Application of the line interception method in sampling range vegetation. J. of Forestry. 39:388-394.

Capinera, John L. 1978. Studies of host preference and suitability exhibited by early-instar range caterpillar larvae. Env. Ent. 7:738-740.

Huddleston, E.W., E.M. Dressel, and J.G. Watts. 1976. Economic threshhold for range caterpillar larvae on blue grama pasture in northeastern Lincoln Co., New Mexico in 1975. New Mexico State Univ. Agr. Exp. Sta. Res. Rep. No. 3144 p.

Levy, E.B., and E.A. Madden. 1933. The point method of pasture analysis. New Zealand .J. Agr. 46:267-279.

Soil Survey Staff. 1975. Soil Taxonomy. U.S. Dep. Agr. S.C.S., Agr. Handbook No. 436.754 p.

Southwood, T.R.E 1978. Ecological Methods. 2nd Ed. Chapman and Hall, London. $524 \mathrm{p}$.

Tomanek, G.W. 1969. Dynamics of mulch layer in grassland ecosystems. C.S.U. Range Sci. Series No. 2:225-240.

Watts, J.G., and T.D. Everett. 1976. Biology and behavior of the range caterpillar. New Mexico State University Agr. Exp. Sta. Bull. No. 646. 31 p.

Whittaker, R.H. 1975. Communities and Ecosystems. McMillan Publishing Co., Inc., New York. 387 p.

Wildermuth, V.L., and D.J. Caffrey. 1916. The New Mexico range caterpillar and its control. U.S. Dep. Agr. Bull. No. 443. 12 p

\title{
Now Available!
}

\section{Trees and Shrubs of the Southwestern Deserts}

\author{
REVISED \& EXPANDED THIRD EDITION \\ by Lyman Benson \& Robert A. Darrow
}

\begin{abstract}
An authoritative guide to the identification of nearly $\mathbf{5 0 0}$ trees and shrubs-including woody vines, borderline bushes, and plants found mostly outside the desert but known to occur within its edges. This comprehensive volume features $\mathbf{4 0}$ color plates, 424 photos and drawings, and 252 maps. $9 \times 12$, double column format, 416 pages. $\$ 49.50$ clothbound. (Please add \$1 postage for mail orders.)
\end{abstract}

\section{The University of Arizona Press}

BOX 3398 -R, TUCSON, ARIZONA 85722 